\title{
Degradation and Detoxicity of Tetracycline by an Enhanced Sonolysis
}

\author{
Chikang WANG, Jhong-Jheng JIAN \\ Department of Environmental Engineering and Health, Yuanpei University of Medical \\ Technology, 306 Yuanpei St., Hsinchu, Taiwan
}

\begin{abstract}
Tetracycline is named by its four special benzene rings in molecular structure, which has been proven as a strong inhibition chemical for many kinds of bacterial. To solve the problem of residual tetracycline containing in municipal and medicine industrial wastewater effluents, this study tried to combine the ultrasound with transition metals (including $\mathrm{Co}^{2+}, \mathrm{Ag}^{+}$and $\mathrm{Fe}^{2+}$ ) and oxidizing agents (persulphate ions, $\mathrm{S}_{2} \mathrm{O}_{8}{ }^{2-}$ and hydrogen peroxide, $\mathrm{H}_{2} \mathrm{O}_{2}$ ) with a continuous dosing mode as an innovative "Enhanced sonolysis" for degrading the tetracycline. Experimental results indicated that the addition of $\mathrm{Fe}^{2+}$ and $\mathrm{H}_{2} \mathrm{O}_{2}$ with ultrasound showed the better performance than other combinations by $\mathrm{Co}^{2+}, \mathrm{Ag}^{+}$and $\mathrm{S}_{2} \mathrm{O}_{8}{ }^{2-}$. As the ultrasound coupled with $0.2 \mathrm{mM} \mathrm{Fe}^{2+}$ and $2 \mathrm{mM} \mathrm{H}_{2} \mathrm{O}_{2}$, more than $90.7 \%$ and $45.9 \%$ of tetracycline were degraded and mineralized. In addition, the toxicity was significantly reduced while the cell viability increased from $53.1 \%$ (un-treated) to $87.5 \%$ (treated). Effect of $\mathrm{pH}$ on the degradation of tetracycline in this study was insignificant but $\mathrm{pH} 3$ showed the better efficiency. It was concluded that the enhanced sonolysis was effective on the degradation, mineralization and detoxicity of tetracycline solution.
\end{abstract}

Keywords: cell viability, continuous dosing mode, enhanced sonolysis, tetracycline, transition metals

\section{INTRODUCTION}

Among a wide variety of pharmaceutical compounds, tetracycline antibiotics are one of the largest groups of pharmaceutical compounds extensively used in human and veterinary medicine to treat and prevent bacterial infections (Esplugas et al., 2007). Tetracycline is an antibiotic chemical with a molecular formula of $\mathrm{C}_{22} \mathrm{H}_{24} \mathrm{~N}_{2} \mathrm{O}_{8}$ and is the antibiotic second highest in production for human and animal treatment of infectious disease (Sarmah et al., 2006; Kummerer, 2009). Because it is water soluble, biologically active, stable and non-biodegradable, release to the environment threatens aquatic life and increases the risk posed by antibiotic-resistant pathogens (Kotzerke et al., 2008; Tao et al., 2010; Su et al., 2012). Additionally, high dosage of tetracycline used in animals lead to the release of residual tetracycline into the surface water and ground water systems then be accumulated in reservoirs; this will cause an environmentally circulated pollution and thus constitute a public health concern (Jiao et al., 2008; Homem and Santos, 2011). It is imperative to remove tetracycline from water adequately.

In practice, due to its antibacterial nature, tetracycline can't be effectively destructed by traditional biological methods. Hence, many researchers tried to use chemical processes such as the photo-Fenton (Bautitz and Nogueira, 2007), electrochemical process (Zhang et al., 2009), ultrasound/goethite/ $\mathrm{O}_{3}$ (Wang et al., 2011) and ultrasound $/ \mathrm{Fe}_{3} \mathrm{O}_{4} / \mathrm{Na}_{2} \mathrm{~S}_{2} \mathrm{O}_{8}$ (Hou et al., 2012) to degrade the tetracycline. Based on the results shown in above studies, the strength of introduced energy by ultraviolet (UV) light or ultrasound,

Address correspondence to Chikang Wang, Department of Environmental Engineering and Health, Yuanpei University of Medical Technology, Email: ckwang@mail.ypu.edu.tw; ckwang168@yahoo.com.tw Received December 25, 2014, Accepted March 11, 2015. 
additions of $\mathrm{H}_{2} \mathrm{O}_{2}$ or iron-salts and $\mathrm{pH}$ affect the efficiency of tetracycline degradation. Among several available advanced oxidation processes (AOPs), the sonochemical oxidation has been demonstrated as a promising method for the degradation of aqueous refractory compounds (Wang and Liu, 2014) due to its advantages of being non-selective and without secondary pollution. Wang et al. (2011) reported that the increase of ultrasonic watts (W) led to the increase of tetracycline degradation and a synergistic effect was achieved in by the combination of ozone and ultrasound. Hou et al. (2012) combined the ultrasound with $\mathrm{S}_{2} \mathrm{O}_{8}{ }^{2-}$ and $\mathrm{Fe}_{3} \mathrm{O}_{4}$ to degrade tetracycline and found that the combination of $\mathrm{Fe}_{3} \mathrm{O}_{4}$ and ultrasound irradiation could significantly enhance magnetite-activated $\mathrm{S}_{2} \mathrm{O}_{8}{ }^{2-}$ oxidation of tetracycline; after 90 min reaction, $89.0 \%$ tetracycline could be removed. Wang et al. (2013a) used the sole ultrasound to degrade tetracycline with an ultrasonic energy of $400 \mathrm{~W}$ and found that $81.0 \%$ of initiated $10 \mathrm{mg} / \mathrm{L}$ tetracycline was degraded within 60 min treatment.

Even the above studies showed that the tetracycline could be readily degraded by ultrasound coupling with ozone or $\mathrm{Fe}_{3} \mathrm{O}_{4} / \mathrm{S}_{2} \mathrm{O}_{8}{ }^{2-}$, the mineralization of tetracycline were not discussed; how to enhance the degradation of tetracycline and shorten the treatment duration based on sonochemical system is needed to be further investigated. Our previous studies (Ma, 2012; Wang et al., 2013b; Wang and Liu, 2014) found that a continuous dosing procedure of chemicals into the reactor was effective on the enhancement of refractory compounds degradation in sonochemical systems. Hence, in this study, an enhanced sonolysis, namely, a combination of ultrasound with three transition metals $\left(\mathrm{Fe}^{2+}, \mathrm{Ag}^{+}\right.$and $\left.\mathrm{Co}^{2+}\right)$ and two oxidizing agents $\left(\mathrm{H}_{2} \mathrm{O}_{2}\right.$ and $\left.\mathrm{S}_{2} \mathrm{O}_{8}{ }^{2-}\right)$, was conducted to degrade the tetracycline and investigate its feasibility; in addition, the transition metals and oxidizing agents were dosed into the reactor with a continuous dosing procedure ultrasound. The effects of transition metals and oxidising agents (including different combinations and concentrations) and the profiles of toxicity measured by the cell viability before and after treatments were also proposed.

\section{MATERIALS AND METHODS}

\section{Materials}

Tetracycline (analytical standard) was purchased from the Sigma-Aldrich. Other chemical reagents used in this study including $\mathrm{H}_{2} \mathrm{SO}_{4}, \mathrm{NaOH}, \mathrm{FeSO}_{4} \cdot 7 \mathrm{H}_{2} \mathrm{O}, \mathrm{AgNO}_{3}$, $\mathrm{Co}\left(\mathrm{NO}_{3}\right)_{2} \cdot 6 \mathrm{H}_{2} \mathrm{O},\left(\mathrm{NH}_{4}\right)_{2} \mathrm{~S}_{2} \mathrm{O}_{8}$, and an aqueous solution of $\mathrm{H}_{2} \mathrm{O}_{2}(30 \%$, w/w in water $)$ were of the purest grade commercially available, which were used without further purification. To investigate the mineralization of tetracycline, profiles of total organic carbon (TOC) concentration were measured and the potassium hydrogen phthalate $\left(\mathrm{C}_{8} \mathrm{H}_{5} \mathrm{KO}_{4}, \mathrm{KHP}\right)$ was used as the standard chemicals.

\section{Tetracycline degradation and mineralization}

Ultrasonic treatment was carried out with a sonicator (Microson VCX 750, USA) equipped with a sealed converter (Model CV 33) and titanium probe tip (Part. No. 630-0210). The ultrasonic transducer operated at $20 \mathrm{kHz}$ continuously, and the maximum output power is $750 \mathrm{~W}$; in this study, the ultrasonic power was controlled at $100 \mathrm{~W}$. A diazinon sample $(1,000 \mathrm{~mL})$ was added to a cylindrical reactor (with a cooling jacket). Initial concentration of tetracycline was prepared as $50 \mathrm{mg} / \mathrm{L}$ where the $\mathrm{pH}$ value of this solution was around $\mathrm{pH}$ 6.0. A circulating temperature controller was 
equipped to maintain the reaction temperature at $25^{\circ} \mathrm{C}$; the value of the initial $\mathrm{pH}$ in experiments was set at $3-6$ attained by adding $1 \mathrm{~N} \mathrm{H}_{2} \mathrm{SO}_{4}$ as required. Other reaction parameters were designed at $\mathrm{S}_{2} \mathrm{O}_{8}{ }^{2-}$ of $2.0 \mathrm{mM}, \mathrm{H}_{2} \mathrm{O}_{2}$ concentrations of $1-4 \mathrm{mM}$ and $\mathrm{Fe}^{2+}$ concentrations of $0.1-0.4 \mathrm{mM}$. Besides $\mathrm{Fe}^{2+}, \mathrm{Co}^{2+}$ and $\mathrm{Ag}^{+}$(both $0.2 \mathrm{mM}$ ) were also considered as the chemicals to investigate the effect of different oxidizing agents and transition metals on the degradation of tetracycline. In this study, the solutions of oxidizing agents and transition metals were pre-adjusted as desire concentrations then added into the reactor drop by drop with a micro-pump, which was defined as a continuous doing mode process; flow rate of oxidizing agents and transition metals were both $0.5 \mathrm{~mL} / \mathrm{min}$ and total added volume for $60 \mathrm{~min}$ was $60 \mathrm{~mL}$.

\section{Sample analysis}

The concentration of tetracycline was determined with a UV-Vis spectrophotometer (Thermo Scientific GENESYS 10S, USA). Prior to measuring tetracycline concentration profile during the experiments, a calibration curve was developed, and a satisfactory linear regression $\mathrm{R}^{2}$ value of 1.0 was observed. Figure 1 shows the full scan spectrum of tetracycline in the wavelength range of 190 to $1,100 \mathrm{~nm}$ determined by $\mathrm{UV}-\mathrm{Vis}$ spectrophotometry. Two major absorption peaks were observed at wavelengths of 276 and $357 \mathrm{~nm}$. Based on the measurement method cited in Wang et al. (2013a), $357 \mathrm{~nm}$ was identified as the maximum absorption wavelength for the determination of tetracycline concentration. The mineralisation of tetracycline was investigated by determining the TOC concentration using a TOC analyser (TOC-500, Shimadzu, Japan).

The toxicity of tetracycline samples (before and after treatment) was determined based on cell viability, where viability was defined from cell counting. The cell counting steps are detailed below. The water samples were first sterilised by filtration through a $0.25-\mu \mathrm{m}$ Millipore membrane filter (Millipore, Bedford, USA). The rat liver cell line Clone-9 was maintained in Dulbecco's modified Eagle's medium (DMEM) supplemented with $10 \%(\mathrm{v} / \mathrm{v})$ fetal bovine serum, $100 \mathrm{U} / \mathrm{mL}$ penicillin and $100 \mu \mathrm{g} / \mathrm{mL}$

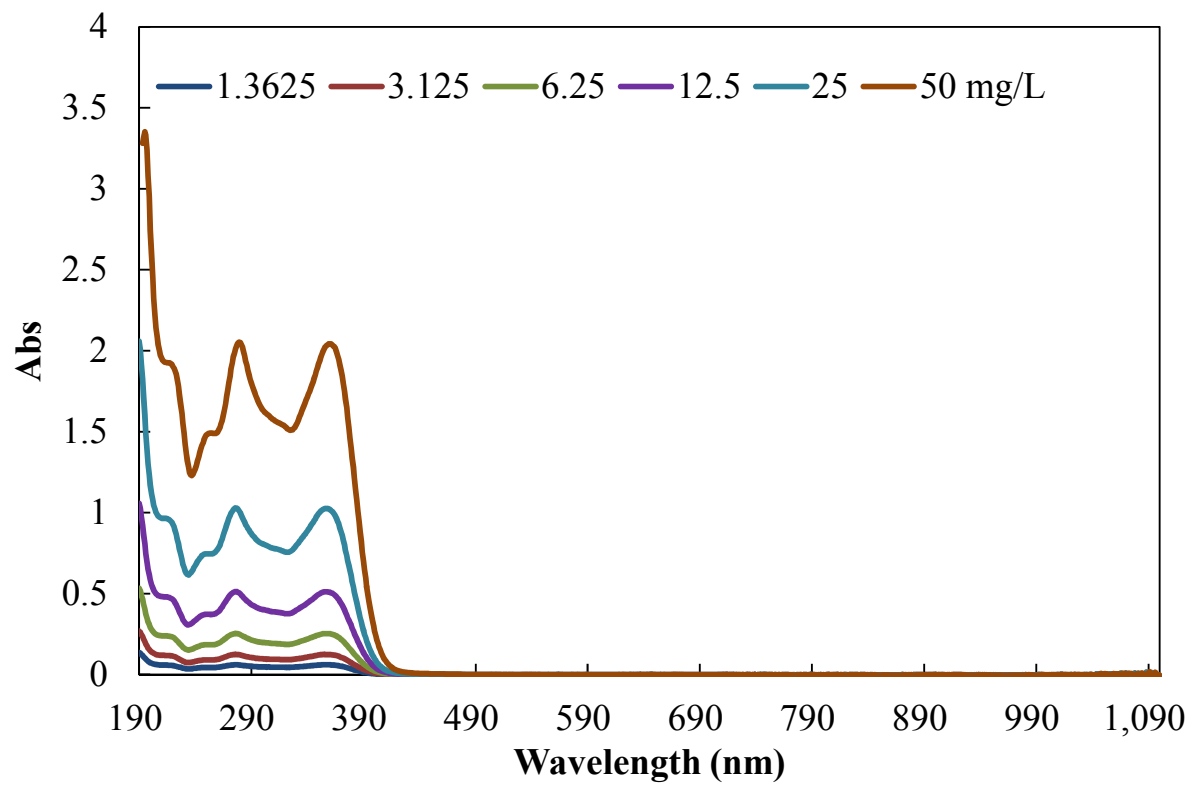

Fig. 1 - Full scan UV-Vis spectrum of tetracycline. 
streptomycin at $37^{\circ} \mathrm{C}$ in a humidified incubator under $5 \% \mathrm{CO}_{2}$. Confluent cultures were passaged by trypsinisation. The cells were washed twice with warm DMEM (without phenol red) and then treated in a serum-free medium. In all experiments, cells were treated with tetracycline water samples for $24 \mathrm{~h}$ before and after oxidation. Cell viability was determined using a blue formazan assay in which colourless 3-(4,5-dimethyl-thiazol-2-yl)-2,5-diphenyl tetrazolium bromide (MTT) is metabolised to a blue product by mitochondrial dehydrogenases. Absorbance was recorded at 540 nm using a SpectraMAX 340 reader. The data were expressed as the mean percent of viable cells compared to the control.

\section{RESULTS AND DISCUSSION \\ Degradation of tetracycline by various processes}

To investigate the feasibility of an enhanced sonolysis in the degradation of tetracycline, this study was first carried out the tetracycline degradation experiments by sole ultrasound $(100 \mathrm{~W})$, ultrasound with transition metals and ultrasound with oxidizing agents, individually, at $\mathrm{pH} 6$ and $25^{\circ} \mathrm{C}$. Degradation of tetracycline with 60 min reaction by sole ultrasound, ultrasound $/ \mathrm{Fe}^{2+}$, ultrasound $/ \mathrm{Ag}^{+}$and ultrasound $/ \mathrm{Co}^{2+}$ were $6.7 \%$, $9.8 \%, 3.8 \%$ and $8.3 \%$, respectively, which indicated that those processes were ineffective on tetracycline degradation. Coupling the oxidizing agents and ultrasound slightly increased the degradation of tetracycline than sole ultrasound where the results were $12.1 \%$ and $19.8 \%$ for ultrasound $/ \mathrm{S}_{2} \mathrm{O}_{8}{ }^{2-}$ and ultrasound $/ \mathrm{H}_{2} \mathrm{O}_{2}$, respectively (data were not shown). Based on previous observations, it was understood that the tetracycline was difficult to be degraded and the combination of ultrasound/transition metals/oxidizing agents was necessary to be carried out for enhancing the degradation.

Figure 2 shows the profiles of tetracycline degradation and mineralization by different enhanced sonolysis processes where the three transition metals were all $0.2 \mathrm{mM}$ and two oxidizing agents were both $2 \mathrm{mM}$. Experimental results indicated that the combination of ultrasound with $\mathrm{Fe}^{2+}$ and $\mathrm{H}_{2} \mathrm{O}_{2}$ effectively degraded and mineralized the tetracycline during the reaction, especially in the first five minutes. During the reaction, this study also monitored the profiles of ORP values and the highest ORP value of 617 $\mathrm{mV}$ (data were not shown) was observed in ultrasound $/ \mathrm{Fe}^{2+} / \mathrm{H}_{2} \mathrm{O}_{2}$ system (original ORP before reaction was around $230 \mathrm{mV}$ ), where the maximum ORP values of other five processes were among $390-555 \mathrm{mV}$. Grčić et al. (2009) indicated that the reaction rate constants in ultrasound $/ \mathrm{Fe}^{2+} / \mathrm{H}_{2} \mathrm{O}_{2}$ or ultrasound $/ \mathrm{Fe}^{2+} / \mathrm{S}_{2} \mathrm{O}_{8}{ }^{2-}$ systems were much higher than ultrasound $/ \mathrm{H}_{2} \mathrm{O}_{2}$ or ultrasound $/ \mathrm{S}_{2} \mathrm{O}_{8}{ }^{2-}$ systems, which was concluded by more $\cdot \mathrm{OH}$ were produced in the presence of $\mathrm{Fe}^{2+}$ then the degradation efficiency was enhanced. This was an evidence that the ultrasound $/ \mathrm{Fe}^{2+} / \mathrm{H}_{2} \mathrm{O}_{2}$ system provided sufficient oxidation power to degrade the tetracycline, and $91.3 \%$ of tetracycline was degrade within 60 min reaction following by $28.0 \%$ TOC removal. In ultrasound $/ \mathrm{Fe}^{2+} / \mathrm{S}_{2} \mathrm{O}_{8}{ }^{2-}$ system, tetracycline degradation and mineralization were $85.1 \%$ and $18.7 \%$, respectively, where the results were slightly lower than ultrasound/ $\mathrm{Fe}^{2+} / \mathrm{H}_{2} \mathrm{O}_{2}$ system. As the $\mathrm{Ag}^{+}$or $\mathrm{Co}^{2+}$ was conducted with $\mathrm{H}_{2} \mathrm{O}_{2}$ or $\mathrm{S}_{2} \mathrm{O}_{8}{ }^{2-}$ in sonolysis, degradation and mineralization of tetracycline were among $35.2 \%-54.8 \%$ and $6.3 \%-13.6 \%$, respectively, which were much lower than the iron-salt system. Therefore, the ultrasound $/ \mathrm{Fe}^{2+} / \mathrm{H}_{2} \mathrm{O}_{2}$ process was considered as the optimal process and the effect of dosing mode and $\mathrm{Fe}^{2+} / \mathrm{H}_{2} \mathrm{O}_{2}$ dosages were investigated in following experiments. 


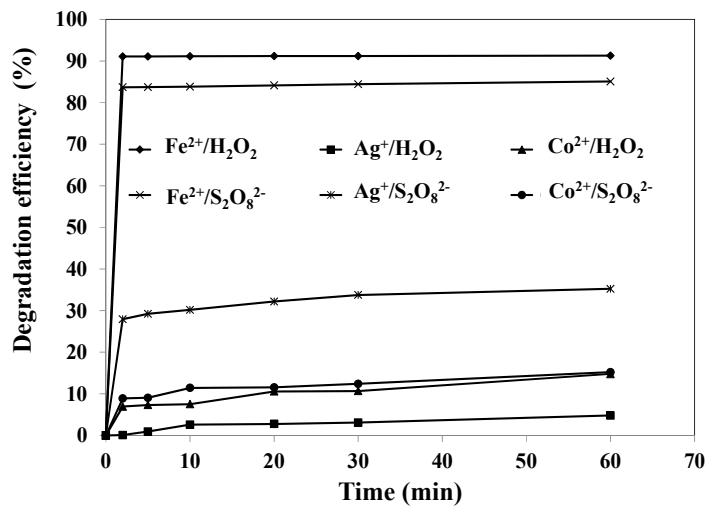

(a)

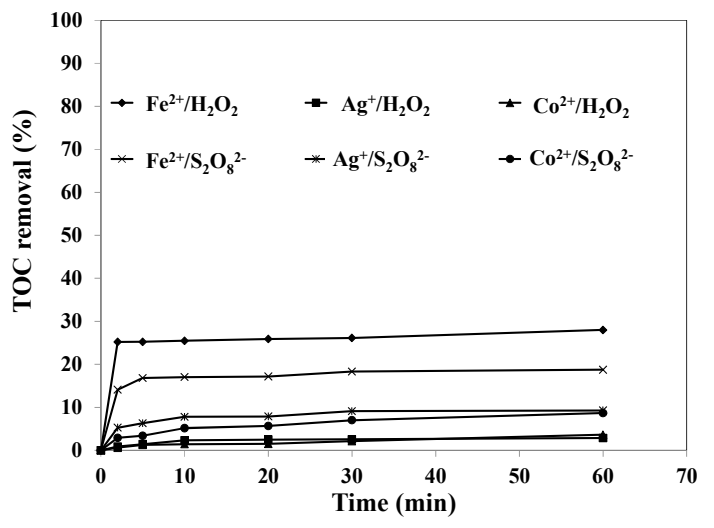

(b)

Fig. 2 - (a) Degradation of tetracycline and (b) mineralization of tetracycline by different enhanced sonolysis processes.

\section{Effect of chemicals dosing mode}

Although the combination of $\mathrm{Fe}^{2+}$ and $\mathrm{H}_{2} \mathrm{O}_{2}$ in sonolysis has been proven as an effective method to degrade refractory compounds (Ling et al., 2010; Lin et al., 2013), exceed chemical dosages in the reaction are disadvantage to the oxidation process and the degradation efficiency might be decreased (Vamathevan et al., 2001; Sun et al., 2009). The "additional dosages" is generally defined as the further increases in $\mathrm{H}_{2} \mathrm{O}_{2}$ and $\mathrm{Fe}^{2+}$ dosages in solution leads to the self-competition to catch the $\cdot \mathrm{OH}$ then the produced - $\mathrm{OH}$ was worthless to react with the pollutants. Therefore, to prevent the exceed $\mathrm{H}_{2} \mathrm{O}_{2}$ and $\mathrm{Fe}^{2+}$ dosing into the solution at the beginning of reaction, our previous studies tried to investigate the degradation of non-biodegradable ethylenediamine with a batch dosing mode (Ma, 2012) and a continuous dosing mode sono-Fenton process (Wang et al., 2013b) and found that the continuous dosing mode sono-Fenton process provided sufficient oxidation potential for the degradation of organic pollutants than a batch dosing mode. In this study, the authors also compare the results of tetracycline degradation and mineralization by a batch dosing mode process and a continuous dosing mode process with same reaction conditions and the results were shown in Table 1.

It is found in Table 1 that the tetracycline degradation with batch dosing mode and continuous dosing mode were comparable at different $\mathrm{H}_{2} \mathrm{O}_{2}$ dosages, where the results were among $90.0 \%$ to $93.2 \%$. This result indicated that the produced $\cdot \mathrm{OH}$ in ultrasound $/ \mathrm{Fe}^{2+} / \mathrm{H}_{2} \mathrm{O}_{2}$ process was effectively reacted with tetracycline and the tetracycline was easily degraded. However, the difference of tetracycline with $\mathrm{H}_{2} \mathrm{O}_{2}$ dosage of $2 \mathrm{mM}$ and $3 \mathrm{mM}$ was insignificant, which was an example that the degradation of tetracycline can't be enhanced with further increase of $\mathrm{H}_{2} \mathrm{O}_{2}$. The TOC removal shows different results. It is found that the TOC removal at $\mathrm{Fe}^{2+} / \mathrm{H}_{2} \mathrm{O}_{2}$ of 0.2 $\mathrm{mM} / 2 \mathrm{mM}$ was much higher than other sets, where the $45.9 \%$ of degraded tetracycline was mineralized as $\mathrm{CO}_{2}$ during the continuous dosing mode ultrasound/ $/ \mathrm{Fe}^{2+} / \mathrm{H}_{2} \mathrm{O}_{2}$ process. This proves that continuous dosing the $\mathrm{Fe}^{2+} / \mathrm{H}_{2} \mathrm{O}_{2}$ reagent into the solution may lead the $\cdot \mathrm{OH}$ is produced sustainably and prevent the self-competition effect. 
Table 1 - Comparison of batch dosing mode process and continuous dosing mode process in tetracycline degradation and mineralization.

\begin{tabular}{|c|c|c|}
\hline Methods/Conditions & Tetracycline degradation & TOC removal \\
\hline Batch mode & & \\
\hline $\mathrm{Fe}^{2+} / \mathrm{H}_{2} \mathrm{O}_{2} 0.2 \mathrm{mM} / 2 \mathrm{mM}$ & $91.3 \%$ & $28.0 \%$ \\
\hline $\mathrm{Fe}^{2+} / \mathrm{H}_{2} \mathrm{O}_{2} 0.2 \mathrm{mM} / 3 \mathrm{mM}$ & $93.2 \%$ & $35.8 \%$ \\
\hline Continuous mode & & \\
\hline $\mathrm{Fe}^{2+} / \mathrm{H}_{2} \mathrm{O}_{2} 0.2 \mathrm{mM} / 2 \mathrm{mM}$ & $90.7 \%$ & $45.9 \%$ \\
\hline $\mathrm{Fe}^{2+} / \mathrm{H}_{2} \mathrm{O}_{2} 0.2 \mathrm{mM} / 3 \mathrm{mM}$ & $90.0 \%$ & $40.0 \%$ \\
\hline
\end{tabular}

\section{Effect of pH}

The $\mathrm{pH}$ level of solution is a key parameter affecting the kinetics of the ultrasound $/ \mathrm{Fe}^{2+} / \mathrm{H}_{2} \mathrm{O}_{2}$ process and most studies adopted acidic conditions attained satisfactory degradation efficiency (Oturan et al., 2008; Wang and Liu, 2014). Based on $\mathrm{pH}$ changing, the nature of organic compound, the scavenge of $\cdot \mathrm{OH}$ by $\mathrm{H}^{+}$and the solubility of iron can affect the pollutant treatments (Ma, 2012). Figure 3 shows the results of tetracycline degradation and mineralization by ultrasound/ $\mathrm{Fe}^{2+} / \mathrm{H}_{2} \mathrm{O}_{2}$ process with $\mathrm{Fe}^{2+}$ and $\mathrm{H}_{2} \mathrm{O}_{2}$ of 0.2 and $2 \mathrm{mM}$, respectively, at different $\mathrm{pH}$ levels. It is found in Fig. 3(a) that the degradations of tetracycline between $\mathrm{pH} 3$ to $\mathrm{pH} 6$ were comparable, where the results were $91.4 \%, 90.5 \%, 90.5 \%$ and $90.9 \%$, respectively, within $60 \mathrm{~min}$ reaction. It is found that the effect of $\mathrm{pH}$ on the degradation of tetracycline was insignificant and the result was similar to the observation in Hou et al. (2012). Gu and Karthikeyan (2005) proposed that the tetracycline was an amphoteric organic compound containing two acidic functional groups (tricarbonyl amide and phenolic diketone) and one basic functional group (dimethyl amine). Therefore, the reaction between $\cdot \mathrm{OH}$ and tetracycline would take place at different position based on the $\mathrm{pH}$ level of solution. As the solution was adjusted as acidic, tricarbonyl amide group will be first reacted with - $\mathrm{OH}$ during the degradation of tetracycline, hence the effect of $\mathrm{pH}$ was insignificant. This is useful information that the tetracycline is unnecessary to be treated at very low $\mathrm{pH}$ level since the ultrasound $/ \mathrm{Fe}^{2+} / \mathrm{H}_{2} \mathrm{O}_{2}$ process is carrying outs. However, as the $\mathrm{pH}$ is greater than $\mathrm{pH} 4$, the produced $\mathrm{Fe}^{3+}$ from Fenton reaction easily precipitate so that the formation of $\bullet \mathrm{OH}$ may decrease. Therefore, the following experiments were still carried out at $\mathrm{pH} 3$. 
Journal of Water and Environment Technology, Vol.13, No.4, 2015

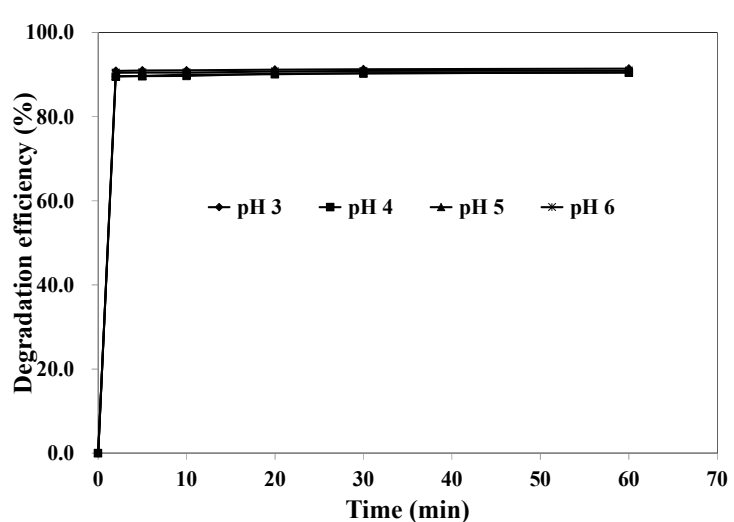

(a)

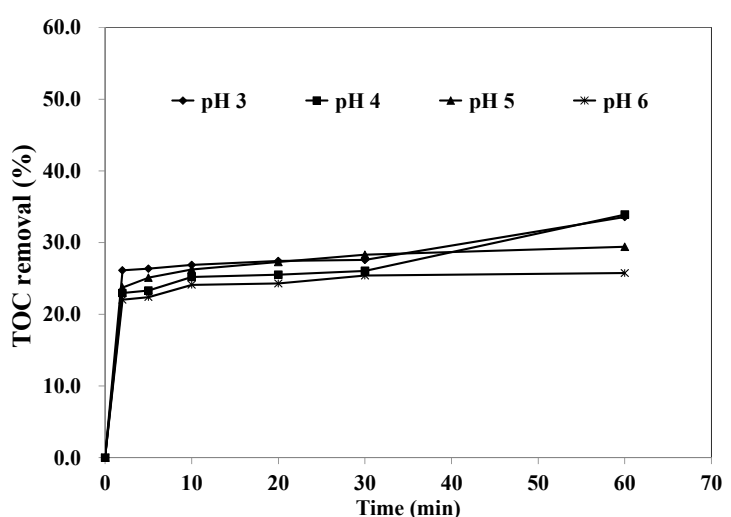

(b)

Fig. 3 - (a) Degradation of tetracycline and (b) mineralization of tetracycline by the ultrasound $/ \mathrm{Fe}^{2+} / \mathrm{H}_{2} \mathrm{O}_{2}$ process at different initial $\mathrm{pH}$ levels.

\section{Effect of $\mathrm{Fe}^{2+}$ and $\mathrm{H}_{2} \mathrm{O}_{2}$ dosages and profiles of toxicity}

In Table 1, as the ultrasound combined with $0.2 \mathrm{mM} \mathrm{Fe}^{2+}$ and $2 \mathrm{mM} \mathrm{H}_{2} \mathrm{O}_{2}$ in continuous dosing mode, degradation of tetracycline reached $90.7 \%$ followed by $45.9 \%$ TOC removal; this indicated that $45.9 \%$ of tetracycline were completely degraded or mineralized as $\mathrm{CO}_{2}$. In addition, as the $\mathrm{H}_{2} \mathrm{O}_{2}$ dosage increased to $3 \mathrm{mM}$, degradation and mineralization of tetracycline decreased. Hence, the effect of Fenton's reagents on the degradation test should be investigated to find out the optimal or profitable conditions. Figure 4(a) shows the results of tetracycline degradation, TOC removal and profiles of cell viability as the tetracycline was degraded by ultrasound $/ \mathrm{Fe}^{2+} / \mathrm{H}_{2} \mathrm{O}_{2}$ process with different $\mathrm{Fe}^{2+}$ dosages $\left(\mathrm{H}_{2} \mathrm{O}_{2}\right.$ was $\left.2 \mathrm{mM}\right)$. It is found that the degradation efficiencies were $88.5 \%, 90.7 \%, 86.0 \%$ and $83.0 \%$ as the $\mathrm{Fe}^{2+}$ dosages increased from $0.1 \mathrm{mM}$ to $0.4 \mathrm{mM}$; also, TOC removals were $40.0 \%, 45.9 \%, 40.9 \%$ and $39.7 \%$, respectively. This indicated that the increase of $\mathrm{Fe}^{2+}$ was valuable in the increase of tetracycline degradation but an excess addition of chemicals had a negative impact on degradation. Özdemir et al. (2011) proposed that the reaction between suitable dosage of $\mathrm{Fe}^{2+}$ and $\mathrm{H}_{2} \mathrm{O}_{2}$ produced satisfactory amount of $\cdot \mathrm{OH}$. However, additional $\mathrm{Fe}^{2+}$ also reacted with $\cdot \mathrm{OH}$ and produced $\mathrm{Fe}^{3+}$ (Eq. 1), which could be defined as a quench effect so that the degradation efficiency of pollutant decreased. In addition, exceed addition of $\mathrm{Fe}^{2+}$ and $\mathrm{Fe}^{3+}$ could cause the production of chemical iron-sludge after wastewater treatment leading to an extra treatment cost for waste sludge (Ma, 2012). To avoid the extra sludge production, the applicable dosage of $\mathrm{Fe}^{2+}$ required to degrade $50 \mathrm{mg} / \mathrm{L}$ tetracycline should be $0.2 \mathrm{mM}$ in this study.

$\mathrm{Fe}^{2+}+\cdot \mathrm{OH} \rightarrow \mathrm{Fe}^{3+}+\mathrm{OH}^{-}$

Figure 4(a) also shows the profiles of cell viability, which was used to evaluate the changes in the toxicity of tetracycline wastewater; the cell viability of blank (RO water) was defined as $100 \%$. It is found that the cell viability of untreated tetracycline was $53.1 \%$ and the results of treated wastewater (after $60 \mathrm{~min}$ ) increased to as high as $87.5 \%$ $\left(\mathrm{Fe}^{2+}\right.$ of $\left.0.2 \mathrm{mM}\right)$, which indicated that the toxicity of treated tetracycline wastewater could be effectively reduced. In addition, a similar trend between TOC removal and cell viability increase was observed (the $\mathrm{R}^{2}$ value of linear relationship simulation was 0.83 ), 
which indicates that the mineralization of tetracycline was the key reaction for toxicity reduction.

To find out the applicable dosage of $\mathrm{H}_{2} \mathrm{O}_{2}$ is also an important objective in wastewater treatments. In Fig. 4(b), the $\mathrm{Fe}^{2+}$ was designed as $0.2 \mathrm{mM}$ and the $\mathrm{H}_{2} \mathrm{O}_{2}$ dosages were ranging from $1 \mathrm{mM}$ to $4 \mathrm{mM}$. It is found that the degradation of tetracycline increased from $76.1 \%$ to $90.7 \%$ as the $\mathrm{H}_{2} \mathrm{O}_{2}$ dosage increased from $1 \mathrm{mM}$ to $2 \mathrm{mM}$. When the $\mathrm{H}_{2} \mathrm{O}_{2}$ dosage increased to 3 and $4 \mathrm{mM}$, degradation of tetracycline slightly decreased to $89.8 \%$ and $89.3 \%$, respectively. A comparable result was observed in TOC removal, where the TOC removals increased from $20.9 \%$ to $45.9 \%$ as the $\mathrm{H}_{2} \mathrm{O}_{2}$ dosage increased from $1 \mathrm{mM}$ to $2 \mathrm{mM}$ and then decreased to $39.9 \%$ and $37.2 \%$ since the $\mathrm{H}_{2} \mathrm{O}_{2}$ dosage were $3 \mathrm{mM}$ and $4 \mathrm{mM}$. This could be explained by the reaction between $\mathrm{H}_{2} \mathrm{O}_{2}$ and produced $\bullet \mathrm{OH}$. Wang and Liu (2014) proposed that more additions of $\mathrm{Fe}^{2+}$ and $\mathrm{H}_{2} \mathrm{O}_{2}$ produced more $\cdot \mathrm{OH}$ and provided higher oxidation potential to degrade the pollutant. However, exceed $\mathrm{H}_{2} \mathrm{O}_{2}$ catching $\bullet \mathrm{OH}$ to produce $\cdot \mathrm{HO}_{2}$ (Eq. 2) then the produced $\bullet \mathrm{OH}$ was insufficient to be applied in pollutant degradation; efficiency of pollutant degradation decreased by exceeding $\mathrm{H}_{2} \mathrm{O}_{2}$ dosage.

$$
\mathrm{H}_{2} \mathrm{O}_{2}+\cdot \mathrm{OH} \rightarrow \cdot \mathrm{HO}_{2}+\mathrm{H}_{2} \mathrm{O}
$$

The results of cell viability profiles shown in Fig. 4(b) were comparable to the tetracycline degradation and TOC removal with different $\mathrm{H}_{2} \mathrm{O}_{2}$ dosages. Before treatment, the cell viability was $53.1 \%$ and slightly increased to $57.2 \%$ as the $\mathrm{H}_{2} \mathrm{O}_{2}$ dosage was $1 \mathrm{mM}$. This result indicated that even $76.1 \%$ of tetracycline was degraded by the ultrasound $/ \mathrm{Fe}^{2+} / \mathrm{H}_{2} \mathrm{O}_{2}$ process, the decrease of toxicity caused by the residual tetracycline and oxidation by-products was insignificant. As the $\mathrm{H}_{2} \mathrm{O}_{2}$ dosage increased to $2 \mathrm{mM}, 3 \mathrm{mM}$ and $4 \mathrm{mM}$, the results of cell viability were $87.5 \%, 81.0 \%$ and $69.5 \%$, respectively. As the data shown in Fig. 4(b), it is found that the degradation of tetracycline in $\mathrm{H}_{2} \mathrm{O}_{2}$ dosages of 2 to $4 \mathrm{mM}$ were all around $90 \%$, which indicated that the degradation of tetracycline was not the key reaction to reduce the toxicity. It is concluded that the appreciate dosage of $\mathrm{H}_{2} \mathrm{O}_{2}$ increased the degradation and mineralization of tetracycline then the toxicity were effectively reduced.

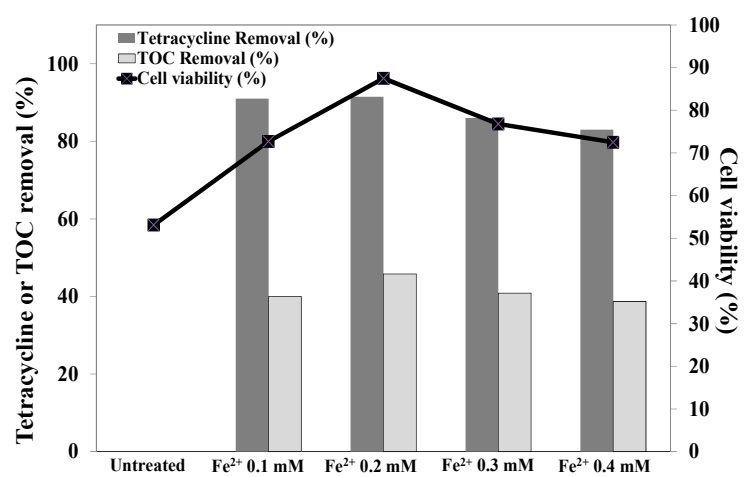

(a)

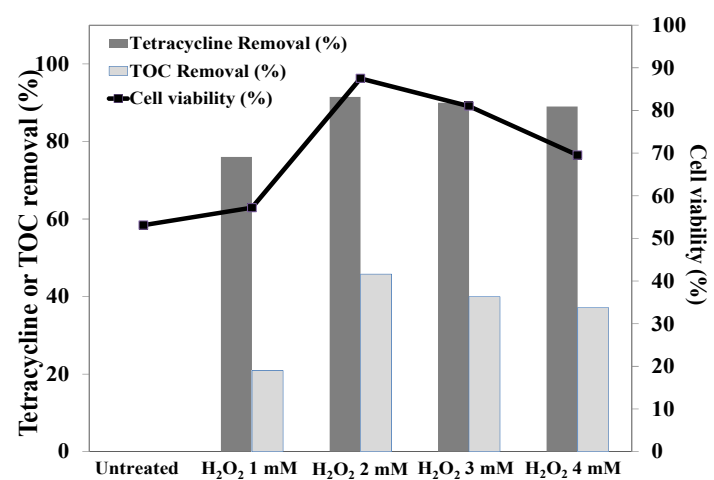

(b)

Fig. 4 - Results of tetracycline degradation, TOC removal and profiles of toxicity at different (a) $\mathrm{Fe}^{2+}$ dosages and (b) $\mathrm{H}_{2} \mathrm{O}_{2}$ dosages. 


\section{CONCLUSIONS}

The degradations of tetracycline in aqueous solution were investigated by an enhanced sonolysis under different experimental conditions, including different transition metals and oxidizing agents, $\mathrm{pH}$ and dosages of $\mathrm{H}_{2} \mathrm{O}_{2}$ and $\mathrm{Fe}^{2+}$. More than $90.7 \%$ tetracycline degradation efficiency combined with $45.9 \%$ mineralization was achieved after 60 minutes reaction time for the initial tetracycline concentration of $50 \mathrm{mg} / \mathrm{L}$ and $\mathrm{H}_{2} \mathrm{O}_{2}$ and $\mathrm{Fe}^{2+}$ dosages of $2 \mathrm{mM}$ and $0.2 \mathrm{mM}$, respectively, at $\mathrm{pH} 3$. Degradation efficiency was enhanced by an increase in the Fenton reagents, $\mathrm{H}_{2} \mathrm{O}_{2}$ and $\mathrm{Fe}^{2+}$, but additional dosages of $\mathrm{H}_{2} \mathrm{O}_{2}$ and $\mathrm{Fe}^{2+}$ had a negative impact on degradation. Effect of $\mathrm{pH}$ on tetracycline degradation was insignificant. The satisfactory result of tetracycline degradation and toxicity decrease proposes that the enhanced sonolysis has the feasibility in the treatment of high strength antibiotic wastewaters in future. Therefore, how to continuously increase the degradation efficiency to reach almost $100 \%$ and achieve the full mineralization of tetracycline need to be further investigation.

\section{ACKNOWLEDGMENTS}

This work was supported by the National Science Council, Republic of China (No. 101-2221-E-264-005) and the Ministry of Science and Technology, Republic of China (grant 103-2221-E-264-001-MY2).

\section{REFERENCES}

Bautitz I. R. and Nogueira R. F. P. (2007) Degradation of tetracycline by photo-Fenton process-Solar irradiation and matrix effects. J. Photochem. Photobiol., A, 187(1), 33-39.

Esplugas S., Bila D. M., Gustavo L., Krause T. and Dezotti M. (2007) Ozonation and advanced oxidation technologies to remove endocrine disrupting chemicals (EDCs) and pharmaceuticals and personal care products (PPCPs) in water effluents. $J$. Hazard. Mater., 149(3), 631-642.

Grčić I., Obradović M., Vujević D. and Koprivanac N. (2009) Sono-Fenton oxidation of formic acid/formate ions in an aqueous solution: from an experimental design to the mechanistic modeling. Chem. Eng. J., 164(1), 196-207.

$\mathrm{Gu}$ C. and Karthikeyan K. G. (2005) Interaction of tetracycline with aluminum and iron hydrous oxides. Environ. Sci. Technol., 39(8), 2660-2667.

Homem V. and Santos L. (2011) Degradation and removal of antibiotics from aqueous matrices. A review. J. Environ. Manage., 92(10), 2304-2347.

Hou L., Zhang H. and Xue X. (2012) Ultrasound enhanced heterogeneous activation of peroxydisulfate by magnetite catalyst for the degradation of tetracycline in water. Sep. Purif. Technol., 84, 147-152.

Jiao S., Zheng S., Yin D., Wang L. and Chen L. (2008) Aqueous photolysis of tetracycline and toxicity of photolytic products to luminescent bacteria. Chemosphere, 73(3), 377-382.

Kotzerke A., Sharma S., Schauss K., Heuer H., Thiele-Bruhn S., Smalla K., Wilke B. M. and Schloter M. (2008) Alterations in soil microbial activity and N-transformation processes due to sulfadiazine loads in pig-manure. Environ. Pollut., 153(2), 315-322.

Kummerer K. (2009) Antibiotics in the aquatic environment - A review. Chemosphere, 
75(4), 417-434.

Lin H., Wu J. and Zhang H. (2013) Degradation of bisphenol A in aqueous solution by a novel electro/ $\mathrm{Fe}^{3+} /$ peroxydisulfate process. Separa. Purifi. Technol., 117, 18-23.

Ling S. K., Wang S. and Peng Y. (2010) Oxidative degradation of dyes in water using $\mathrm{Co}^{2+} / \mathrm{H}_{2} \mathrm{O}_{2}$ and $\mathrm{Co}^{2+} /$ peroxymonosulfate. J. Hazard. Mater, 178(3), 385-389.

Ma Y. S. (2012) Short review: Current trends and future challenges in the application of sono-Fenton oxidation for wastewater treatment. Sustainable Environ. Res., 22(5), 271-278.

Oturan M. A., Sirés I., Oturan N., Pérocheaua S., Laborde J. L. and Trévin S. (2008) Sonoelectro-Fenton process: A novel hybrid technique for the destruction of organic pollutants in water. J. Electroanal. Chem., 624(1-2), 329-332.

Özdemir C., Öden M. K., Şahinkaya S. and Güçlü D. (2011) The sonochemical decolorisation of textile azo dye CI Reactive Orange 127. Color. Technol., 127(4), 268-273.

Sarmah A. K., Meyer M. T. and Boxall A. B. A. (2006) A global perspective on the use, sales, exposure pathways, occurrence, fate and effects of veterinary antibiotics (VAs) in the environment. Chemosphere, 65(5), 725-759.

Su H., Ying G., Tao R., Zhang R., Zhao J. and Liu Y. (2012) Class 1 and 2 integrons, sul resistance genes and antibiotic resistance in Escherichia coli isolated from Dongjiang River, South China. Environ. Pollut., 169, 42-49.

Sun J., Li X., Feng J. and Tian X. (2009) Oxone $/ \mathrm{Co}^{2+}$ oxidation as an advanced oxidation process: Comparison with traditional Fenton oxidation for treatment of landfill leachate. Water Res., 43(17), 4363-4369.

Tao R., Ying G., Su H., Zhou H. and Sidhu J. (2010) Detection of antibiotic resistance and tetracycline resistance genes in Enterobacteriaceae isolated from the Pearl rivers in South China. Environ. Pollut., 158(6), 2101-2109.

Vamathevan V., Tse H., Amal R., Low G. and McEvoy S. (2001) Effects of $\mathrm{Fe}^{3+}$ and $\mathrm{Ag}^{+}$ions on the photocatalytic degradation of sucrose in water. Catal. Today, 68(3), 201-208.

Wang C. K. and Liu Z. H. (2014) Decontamination of alachlor herbicide wastewater by a continuous dosing mode ultrasound $/ \mathrm{Fe}^{2+} / \mathrm{H}_{2} \mathrm{O}_{2}$ process. J. Environ. Sci. (China), 26(6), 1332-1339.

Wang C. K., Hou C. W. and Wei Y. X. (2013b) Degradation and detoxicity of ethylenediamine wastewater by a continuous dosing mode sono-Fenton process. Sustainable Environ. Res., 23(6), 413-420.

Wang X., Wang Y. and Li D. (2013a) Degradation of tetracycline in water by ultrasonic irradiation. Water Sci. Technol., 67(4), 715-721.

Wang Y., Zhang H. and Chen L. (2011) Ultrasound enhanced catalytic ozonation of tetracycline in a rectangular air-lift reactor. Catal. Today, 175(1), 283-292.

Zhang H., Liu F., Wu X., Zhang J. and Zhang D. (2009) Degradation of tetracycline in aqueous medium by electrochemical method. Asia-Pac. J. Chem. Eng., 4(5), 568-573. 